\title{
Topical antibiotics help to reduce sternal infections
}

\author{
Harold L. Lazar, MD
}

See related article on pages 1631-40.

Sternal wound infections continue to be a source of morbidity, mortality, and increased medical costs in patients undergoing cardiac surgery. Furthermore, the US Center for Medicare and Medicaid Services will no longer reimburse hospital costs incurred in the treatment of sternal wound infections after cardiac surgery.

In their review of 14 studies, published in this issue of the Journal, Kowalewski and coworkers ${ }^{1}$ found that implantable gentamicin collagen sponges significantly reduced the risk of both deep and superficial sternal wound infections by $40 \%{ }^{1}$ Mortality was not influenced by implantable gentamicin collagen sponges, however, and these beneficial effects were attenuated in patients receiving bilateral internal thoracic artery grafts, who as a group had a higher incidence of sternal wound infections. These results are at odds with those of the Implantable Gentamicin Collagen Sponge on Sternal Wound Infections Following Cardiac Surgery Trial (SWIPE-1), which failed to show a beneficial effect for implantable gentamicin collagen sponge therapy. ${ }^{2}$ This may have been due to a failure in that trial to follow the manufacturer's sponge implantation protocol, which resulted in longer exposure of the gentamicin sponge in a saline solution before application, thus lowering the concentration of gentamicin in the sponge. ${ }^{3,4}$

The results of the meta-analysis of Kowalewski and coworkers ${ }^{1}$ reinforce the concept that the application of topical antibiotics to the sternum during cardiac surgery significantly reduces the incidence of sternal wound infections. In addition to gentamicin, topical vancomycin has also been shown to reduce significantly the incidence of sternal wound infections. ${ }^{5}$ Recently my own group reported that topical vancomycin applied to the sternal edges in conjunction with perioperative antibiotics and tight glycemic control eliminated all sternal wound infections in 1075 patients undergoing cardiac surgical procedures,

\footnotetext{
From the Division of Cardiac Surgery, Boston Medical Center, Boston, Mass. Disclosures: Author has nothing to disclose with regard to commercial support. Received for publication Jan 30, 2015; accepted for publication Jan 30, 2015; available ahead of print March 5, 2015

Address for reprints: Harold L. Lazar, MD, Division of Cardiac Surgery, Boston Medical Center, 88 E Newton St, B402, Boston, MA 02118 (E-mail: harold. lazar@bmc.org).

J Thorac Cardiovasc Surg 2015;149:1641-2

$0022-5223 / \$ 36.00$

Copyright (C) 2015 by The American Association for Thoracic Surgery

http://dx.doi.org/10.1016/j.jtcvs.2015.01.072
}

among whom $34 \%$ had diabetes mellitus, with $35 \%$ of the patients diabetes dependent on insulin. ${ }^{6}$ Concerns have been raised that the use of topical antibiotics might lead to the emergence of resistant organisms. Although this was not addressed by Kowalewski and coworkers $^{1}$ in the study published here, my coworkers and I found that

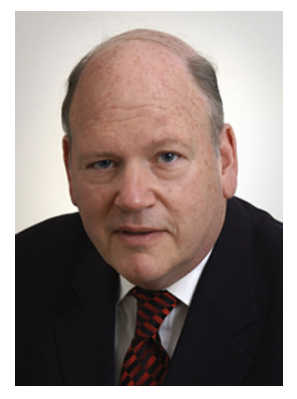
topical vancomycin did not result in persistently elevated postoperative antibiotic levels after 6 days and did not potentiate the emergence of drugresistant infections or contribute to postoperative renal toxicity at 1-year follow-up. ${ }^{6,7}$

The use of perioperative antibiotics, the maintenance of glycemic control with intravenous insulin infusions, and the avoidance of bone wax have all contributed to a decreased incidence of sternal wound infections. ${ }^{8-12}$ This meta-analysis by Kowalewski and coworkers, ${ }^{1}$ along with my own group's studies and those of others, now suggest that topical antibiotics applied to the sternal edges may further reduce or even eliminate all sternal wound infections. Strong consideration should be given to using some form of topical antibiotics in all cardiac surgical patients undergoing median sternotomy.

\section{References}

1. Kowalewski M, Pawliszak W, Zaborowska K, Navarese EP, Szwed KA, Kowalkowska ME, et al. Gentamicin-collagen sponge reduces the risk of sternal wound infections following heart surgery: meta-analysis. J Thorac Cardiovasc Surg. 2015;149:1631-40.

2. Bennett-Guerrero E, Ferguson TB Jr, Lin M, Garg J, Mark DB, Scavo VA Jr, et al Effect of an implantable gentamicin-collagen sponge on sternal wound infections following cardiac surgery: a randomized trial. JAMA. 2010;304 755-62.

3. Friberg Ö, Bodin L. Collagen gentamicin for prevention of sternal wound infection: Effective or not? J Thorac Cardiovasc Surg. 2013;61:185-93.

4. Lovering AM, Sunderland J. Impact of soaking gentamicin-collagen implants and potential antimicrobial efficacy. Int J Surg 2012;10 Suppl $1: \mathrm{S} 2-4$.

5. Vander Salm TJ, Okike ON, Pasque MK, Pezzella AT, Lew R, Traina V, et al. Reduction of sternal wound infection by application of topical vancomycin. $J$ Thorac Cardiovasc Surg. 1989;98:618-22.

6. Lazar HL, Ketchedjian A, Haime M, Karlson K, Cabral H. Topical vancomycin in combination with perioperative antibiotics and tight glycemic control helps to eliminate sternal wound infections. J Thorac Cardiovasc Surg. 2014;148:1035-40, $1038-40$.

7. Lazar HL, Barlam T, Cabral H. The effect of topical vancomycin applied to sternotomy incisions on postoperative serum vancomycin levels. J Card Surg. 2011; 26:461-5.

8. Edwards FH, Engelman RM, Houk P, Shahian VM, Bridges CR, Society of Thoracic Surgeons. The Society of Thoracic Surgeons Practice Guidelines: antibiotic prophylaxis in cardiac surgery, part 1: duration. Ann Thorac Surg. 2006;81 397-404. 
9. Lazar HL, Chipkin SR, Fitzgerald CA, Bao Y, Cabral H, Apstein CS. Tight glycemic control in diabetic coronary artery bypass graft patients improves perioperative outcomes and decreases recurrent ischemic events. Circulation. 2004; 109:1497-502.

10. Kerr KJ, Funary AP, Grunkemeier GL, Bookin S, Kanhere B, Starr A. Glucose control lowers the risk of wound infection in diabetics after open heart operations. Ann Thorac Surg. 1997;63:356-61.
11. Nelson DR, Buxton TB, Luu QN, Rissing JP. The promotional effect of bone wax in experimental Staphylococcus aureus osteomyelitis. J Thorac Cardiovasc Surg. 1990;99:977-80.

12. Wellisz T, Armstrong JK, Cambridge J, An YH, Wen X, Kang Q, et al. The effects of a soluble polymer and bone wax on sternal healing in animal model. Ann Thorac Surg. 2008;85:1776-80, Erratum in: Ann Thorac Surg. 2008;86: 1403. 